\title{
Analytical in vitro approach for studying cyto- and genotoxic effects of particulate airborne material
}

\author{
Michaela Aufderheide • Stefanie Scheffler • \\ Niklas Möhle • Beat Halter • Dieter Hochrainer
}

Received: 15 April 2011 /Revised: 30 May 2011 /Accepted: 2 June 2011 /Published online: 22 June 2011

(C) The Author(s) 2011. This article is published with open access at Springerlink.com

\begin{abstract}
In the field of inhalation toxicology, progress in the development of in vitro methods and efficient exposure strategies now offers the implementation of cellular-based systems. These can be used to analyze the hazardous potency of airborne substances like gases, particles, and complex mixtures (combustion products). In addition, the regulatory authorities require the integration of such approaches to reduce or replace animal experiments. Although the animal experiment currently still has to provide the last proof of the toxicological potency and classification of a certain compound, in vitro testing is gaining more and more importance in toxicological considerations. This paper gives a brief characterization of the CULTEX ${ }^{\circledR}$ Radial Flow System exposure device, which allows the exposure of cultivated cells as well as bacteria under reproducible and stable conditions for studying cellular and genotoxic effects after the exposure at the air-liquid or air-agar interface, respectively. A commercial bronchial epithelial cell line (16HBE14o-) as
\end{abstract}

Published in the special issue Aerosol Analysis with guest editor Ralf Zimmermann.

Electronic supplementary material The online version of this article (doi:10.1007/s00216-011-5163-4) contains supplementary material, which is available to authorized users.

M. Aufderheide $(\bowtie) \cdot$ S. Scheffler $\cdot$ N. Möhle

CULTEX Laboratories $\mathrm{GmbH}$,

Feodor-Lynen-Str. 21,

30625 Hannover, Germany

e-mail: m.aufderheide@cultex-laboratories.com

B. Halter

Halter Engineering $\mathrm{GmbH}$,

Huebstr. 16,

9100 Herisau, Switzerland

D. Hochrainer

Vor der Hardt 16,

57392 Oberkirchen, Germany well as Salmonella typhimurium tester strains were exposed to smoke of different research and commercial available cigarettes. A dose-dependent reduction of cell viability was found in the case of 16HBE14o- cells; S. typhimurium responded with a dose-dependent induction of revertants. The promising results recommend the integration of cellular studies in the field of inhalation toxicology and their regulatory acceptance by advancing appropriate validation studies.

Keywords Inhalation toxicology $\cdot$ CULTEX ${ }^{\circledR}$ RFS module Electrical deposition - Air-liquid interface . Cigarette smoke $\cdot$ Ames assay

\section{Introduction}

The respiratory tract is the main entry for ambient air pollutants like gases, volatile compounds, or particles. Accordingly, acute cyto- and genotoxic effects as well as chronic alterations, ranging from reversible cellular changes to persistent modifications of the airways, are the major effects on human health. Due to the fact that the incidence of lung disease is also increasing $[1,2]$ as a major cause of lethality, the studies in the field of inhalation toxicology concentrate on the understanding of mechanisms of lung injury and repair as well as the toxicological characteristics and potency of inhalable substances. Usually, these adverse biological effects are studied in animal experiments, but the European Guideline Registration, Evaluation and Authorization of Chemicals (REACH) demands the reduction and replacement of animal experiments for logistical and ethical reasons. Thus, there is an urgent need to develop, establish, and validate alternative test methods as well as new relevant test strategies to analyze airborne material. In the case of inhalable material, there are challenges concerning 
the exposure procedure, the determination of dose-response relationships, and relevant endpoints.

In order to use such alternative systems of the respiratory tract for studying the effect of airborne compounds like gases, particles, or complex aerosols like cigarette smoke or diesel exhaust, special devices for direct exposure of cultivated cells or bacteria were established [3-9]. The idea of Tarkington et al. [10] to guide the atmosphere via a vertical dynamic stream directly to the biphasic cultivated test organisms, was optimized in a new exposure system called CULTEX ${ }^{\circledR}$ Radial Flow System (RFS).

The basic considerations for such a direct exposure system mimicking the inhalation cycle in vivo are: (a) relevant cell or test models, (b) cultivation of the biological systems at the air-liquid interface (ALI), (c) direct contact between the test organisms and airborne material, in the case of cultivated cells without interfering medium and (d) uniform exposure with the test material. The exposure can be conducted directly under dynamic conditions, meaning the continuous generation and transport of the test atmosphere to the cells or bacteria, a directed aerosol stream to the surface of the test organisms, a homogeneous exposure as well as a reproducible deposition of particles, and the continuous removal of the atmosphere.

Ideally, human cells of the respiratory tract should be analyzed for cytotoxic and genotoxic investigations to avoid species-specific discussion concerning the relevance of the estimated effects. A variety of commercial cell lines like A549, BEAS-2B, Calu-3, and 16HBE140- as well as primary epithelial cells (e.g., NHBE cells, Lonza Group Ltd., Switzerland; HBEpC, PromoCell GmbH, Germany) are also available in addition to ready-to-use cell culture systems (EpiAirway ${ }^{\mathrm{TM}}$, MatTek Corporation; MucilAir ${ }^{\mathrm{TM}}$, Epithelix Sàrl) and can be used, for example, in screening and drug absorption studies [11-17]. Furthermore, multilayered systems and tissue equivalents composed of different cell populations (e.g., fibroblasts, macrophages, and endothelial cells in combination with epithelial cells) are described, which are suitable for more sophisticated studies [18-24].

Bacterial systems can also be included in studies investigating the genotoxic potency of airborne material in the Ames assay by using strains of Salmonella typhimurium and Escherichia coli. A miniaturization of the Ames assay in agreement with the OECD guideline 471 allows the estimation of a dose-related induction of revertants after exposure of the bacteria at the air-agar interface $[25,26]$.

The exposure technique itself involves (1) the adjusted generation of the test atmosphere, (2) the exposure process, and (3) the analysis of the biological reactions of the test organisms. The whole process must be controlled with regard to medium supply of the cells, the flow rate of the aerosol above the cells as well as the deposition rate of the test atmosphere for calculating the exposure dose. By taking into consideration all these aspects, it is possible to create stable and reproducible experimental conditions resulting in the estimation of dose-response relationships for the actual test atmosphere. Examples of such studies using cellular and bacterial test organisms exposed to cigarette smoke are presented as well as the theoretical considerations forming the basis for the efficiency of the CULTEX $^{\circledR}$ RFS module.

\section{Materials and methods}

\section{Smoke generation}

For the generation of mainstream cigarette smoke, a varying number (one to eight cigarettes) of K3R4F (9.4 mg tar/ cigarette) and K1R5F (1.67 mg tar/cigarette) cigarettes (University of Kentucky Tobacco and Health Research Institute in Lexington, KY, USA) were smoked on a smoke robot according to ISO 3308 guidelines ( $35 \mathrm{ml}$ puff volume, $2 \mathrm{~s}$ duration, one puff/min) for exposing 16HBE140- cells at the air-liquid interface. To study the genotoxic potency of cigarette smoke, the list of cigarettes was extended by a monitor cigarette CM5 (15 mg tar/cigarette) and a commercial brand with a tar content of $7 \mathrm{mg}$ tar/cigarette (code: $\mathrm{C} 1$ ). The freshly generated smoke was diluted with a constant flow of synthetic air $(0.5$ and $1.0 \mathrm{l} / \mathrm{min})$ in a mixing chamber controlled by mass flow controllers. In this way, the discontinuously generated smoke was diluted and converted into a continuous aerosol flow (cell exposure, flow rate of $5 \mathrm{ml} / \mathrm{min}$ and exposure of bacteria, $10 \mathrm{ml} / \mathrm{min}$ ) which was sucked via negative pressure from a vacuum pump through the CULTEX ${ }^{\circledR}$ RFS module shown in Fig. 1 (CULTEX ${ }^{\circledR}$ Laboratories, Hannover, Germany).

The flow rates for each position within the module were controlled separately by flow controllers to guarantee a homogeneous gas stream and particle deposition over the exposure positions. During the intervals of puff generation, the test organisms were exposed to synthetic air. The physical forces driving deposition of airborne material are: (1) sedimentation, (2) diffusion, (3) electrical forces, and (4) inertial impaction when using a very small flow through the module to avoid an evaporation of the cells. The theoretical consideration forming the basis of the efficiency of the system can be found in the Electronic Supplementary Material (ESM).

Bacterial strains and culture conditions

The genotoxic potency of cigarette smoke was analyzed with the Ames assay by using the tester strains $S$. typhimurium TA 98 (frame-shift mutation) for whole cigarette smoke and 


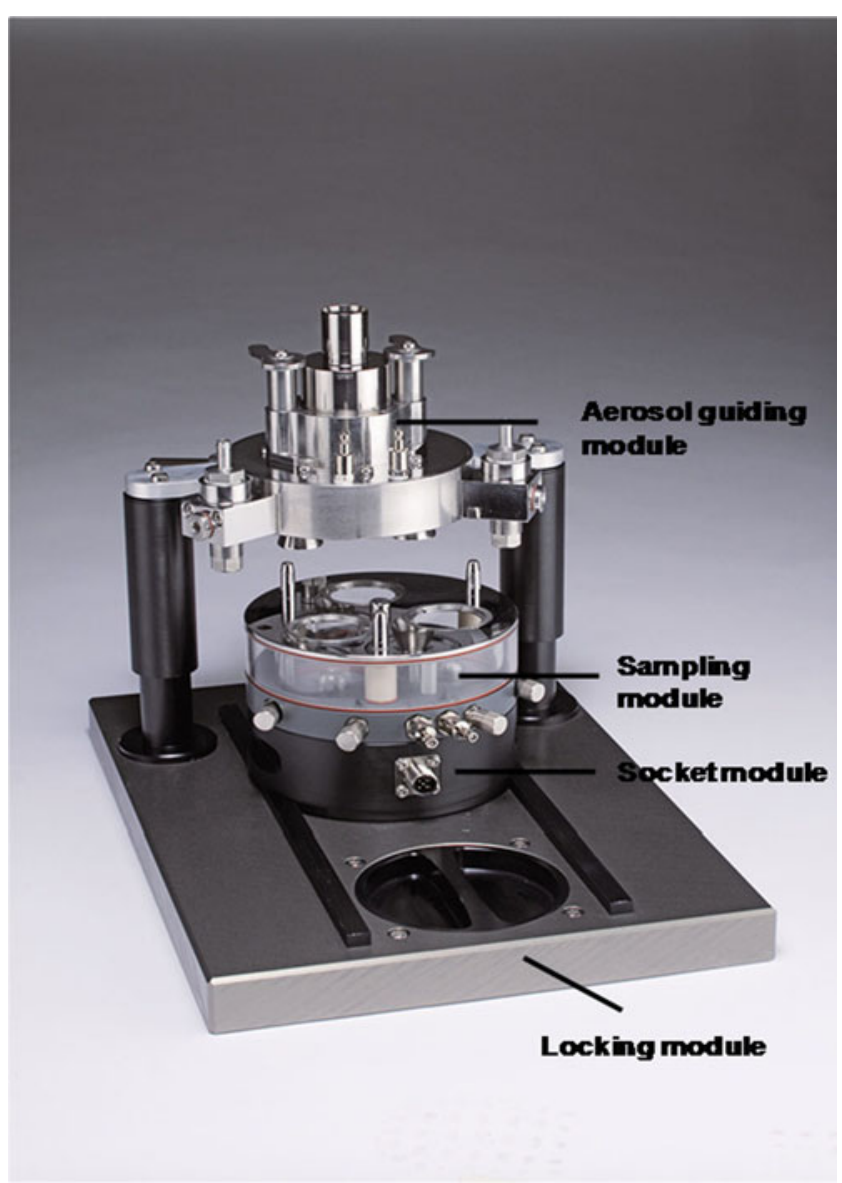

Fig. 1 The modularly designed CULTEX ${ }^{\circledR}$ Radial Flow System is composed of four basic components: the aerosol guiding module, the sampling module, the socket module, and the locking module. The construction allows comfortable handling and loading of the system with the cell culture inserts. The insertion of adapters for cell culture inserts of different size and manufacturers make the system very flexible

strain S. typhimurium TA 100 (missense mutation) for the gas vapor phase (University of California, Berkeley, USA). Single colonies were isolated and strain characteristics were checked according to Maron and Ames [27]. A frozen bacterial stock suspension was grown overnight at $37^{\circ} \mathrm{C}$ in a shaking incubator in $20 \mathrm{ml}$ nutrient broth. Bacteria were in the late log phase when used. To calculate the bacterial number before seeding them onto the agar, aliquots of the bacterial suspension were counted using an automated cell counter and analyzer system (CASY Modell TT, Schärfe System GmbH, Reutlingen, Germany). The bacteria were seeded in Petri dishes of minimized scale $(35 \mathrm{~mm}$ in diameter, Nunc \#150318) with and without overlay agar (spread culture) $[25,26]$.

\section{Mutagenicity assay}

The overlay agar Method was consistent with the method published by Maron and Ames [27]. Using the spread culture method [28], the bacteria were poured directly onto the selective agar plates (composition: $1.5 \%$ agar, $2 \%$ glucose, Vogel/Bonner medium) already complemented with a histidine/biotin solution $(0.5 \mathrm{mM})$. Concurrent negative and positive controls (according to OECD guideline 471) were performed in all experiments testing solvent substances. To show the mutagenic capacity of strains TA98 under conventional conditions, positive control substances (the directly acting mutagen 2-nitrofluorene and the indirectly acting mutagen 2-amino-anthracene) were used. DMSO served as negative control. In the case of direct exposure, synthetic air $\left(20.5 \% \mathrm{O}_{2}\right.$ in $\left.\mathrm{N}_{2}\right)$ was used as a negative control whereas $\mathrm{NO}_{2}$, delivered from gas flasks (Messer-Griesheim, Krefeld, Germany), was used as a positive control gas to induce mutagenic effects. Different concentrations were obtained by mixing with synthetic air, controlled by rotameters.

All testing was done using triplicate plates for each dosage and experiments were repeated three times. After exposure, the plates were incubated at $37^{\circ} \mathrm{C}$ for $48-72 \mathrm{~h}$. For metabolic activation, the $\mathrm{S} 9$ fraction was obtained from the Cytotest Cell Research GmbH (Rossdorf, Germany), prepared from phenobarbital/naphthoflavone-induced rat liver (Wistar) and stored in liquid nitrogen until use. The metabolic activation system consisted of $16.7 \mathrm{ml}$ PBS $(0.2 \mathrm{M}, \mathrm{pH} 7.4), 0.4 \mathrm{ml}$ potassium chloride $(1.65 \mathrm{M})$ and magnesium chloride $(0.4 \mathrm{M}), 0.1 \mathrm{ml}$ glucose-6-phosphate $(1 \mathrm{M}), 0.8 \mathrm{ml}$ NADP $(0.1 \mathrm{M})$, and $2.0 \mathrm{ml} \mathrm{S} 9$ fraction. All experiments with mainstream smoke were conducted with S9 mix whereas all gas vapor phase (GVP) experiments were performed without S9 mix.

The data were counted automatically with the PROTOCOLCounter (Synbiosys, Cambridge, UK). The smoke was considered to be toxic when reduced growth of the bacteria (smaller number and/or smaller colonies) on the selective agar plates occurred, or when a reduced background lawn was observed.

In the Ames assay, a strain was defined as sensitive if there was a reproducible demonstration of concentrationrelated effects with a 2-fold increase in the number of revertants over the spontaneous frequency of revertants. If the number of revertants was below ten, at least 3-fold increase of revertants was required. In addition, the background lawn should be close to the nontoxic concentration and the number of revertants should be within accepted ranges [29].

\section{Human bronchial epithelial cell line}

The human bronchial epithelial cell line (16HBE14o-) cells (Professor Gruenert, University of California, San Francisco, USA) are immortalized human bronchial epithelial cells (simian virus 40) that form polarized cell layers with intact tight junctions and feature many characteristics of primary 
cells [14]. Under ALI conditions, 16HBE14o- cells were able to differentiate into ciliated cells. The 16HBE14o- cells were cultivated in cell culture flasks and microporous insert membranes coated with a mixture containing collagen type I and human fibronectin. As general growth medium, MEM with Earle's salts (including stable L-glutamine; Biochrom FG 0325) supplemented with $10 \%$ fetal calf serum and penicillin/streptomycin was used. The seeding density, subculturing time point and the growth area of culture vessels were each adapted to the requirements of the experiments. In general, an overgrowth was avoided.

\section{WST assay}

The Cell Proliferation Reagent WST-1 (Roche Diagnostics $\mathrm{GmbH}$ ) is a nonradioactive, ready-to-use substrate which measures the metabolic activity of viable cells. It is suitable for measuring cell proliferation, cell viability or cytotoxicity. The assay is based on the reduction of WST-1 by viable cells. The reaction produces a soluble formazan salt. The amount of formazan, which is proportional to the mitochondrial activity of the cells, is quantified by measuring the light absorbance at $450 \mathrm{~nm}$.

In order to analyze the mitochondrial activity of cigarette smoke-exposed cells, $550 \mu \mathrm{L}$ of WST-1 reaction solution $(500 \mu \mathrm{L}$ cell culture medium $+50 \mu \mathrm{L}$ WST- 1$)$ was added on the surface of the cells. After 1-h incubation at $37{ }^{\circ} \mathrm{C} / 5 \%$ $\mathrm{CO}_{2}, 100 \mu \mathrm{L}$ solution was taken out of each well, pipetted into a 96-well plate and read out at $450 \mathrm{~nm}$.

\section{Results}

\section{Acute cytotoxicity}

In a series of experiments, the CULTEX ${ }^{\circledR}$ RFS was applied to investigate acute cytotoxicity of whole mainstream cigarette smoke on human bronchial epithelial cells (16HBE140-) after direct exposure at the ALI. The immortalized cell line is characterized by functional tight junctions and an active ion transport. The cells were grown on microporous membranes (growth area of the insert vessel, $1 \mathrm{~cm}^{2}$ ) and exposed to mainstream smoke of various numbers (one to eight cigarettes) of Kentucky research cigarettes K3R4F (9.4 mg tar/ cigarette) and K1R5F (1.67 mg tar/cigarette). In parallel to smoke exposure, another set of cells were exposed to clean air in order to exclude damaging effects due to the methodical setup (clean air control) or remained, as a second control (incubator air-lifted culture) in the incubator and were analyzed simultaneously to the exposed cells. $9.48 \%(w / w)$ of the incoming smoke particles were deposited on filters (SD, $\pm 0.33 \%$ ) placed in the inserts, thus pointing to a homogeneous, stable and reproducible particle exposure.
After a post-incubation time of $24 \mathrm{~h}$ at $5 \% \mathrm{CO}_{2} / 37{ }^{\circ} \mathrm{C}$, the cells were investigated for cell viability (WST-1 assay) and the data of the smoke-exposed cells were normalized to the values of the clean air control for each time point. In Fig. 2a, the results of the exposure experiments show a clear dose-response relationship for the high-tar cigarette. No cytotoxic effect was found after exposure to mainstream smoke of one cigarette. By increasing the number of cigarettes, cell viability decreased. The exposure of eight cigarettes induced an almost complete loss of cell viability. The values of the incubator-control cells were comparable to those exposed to clean air at each time point (data not shown) and were, thus, considered no further. The exposure of the cells to the low-tar cigarette revealed no sign of toxicity if the cells were exposed to the smoke of up to ten cigarettes. Cytotoxic effects are primarily visible after

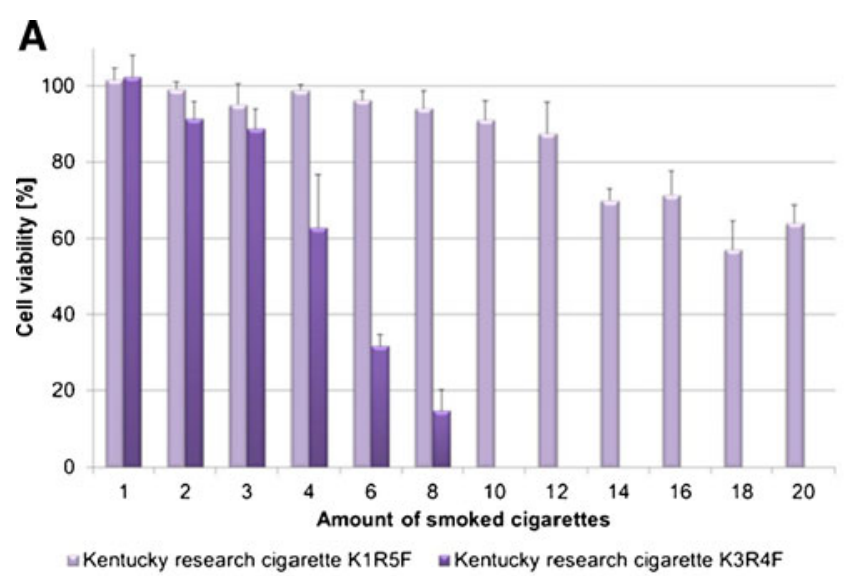

B

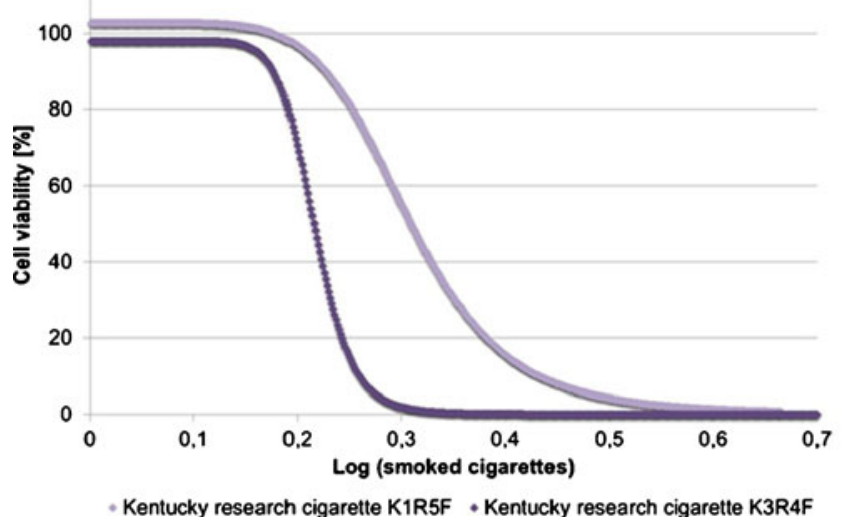

Fig. 2 A Cell viability of undifferentiated 16HBE14o- cells after the exposure to mainstream smoke of increasing numbers of Kentucky research cigarettes $\mathrm{K} 3 \mathrm{R} 4 \mathrm{~F}$ and $\mathrm{K} 1 \mathrm{R} 5 \mathrm{~F}$. The cell viability was measured $24 \mathrm{~h}$ after the exposure performing the WST-1 assay and normalized to the viability of clean-air-exposed cells. The values are given as mean of three replicates + standard deviation. B Doseresponse curve for $16 \mathrm{HBE} 14 \mathrm{o}-\mathrm{c}$ lls after the exposure to mainstream smoke of increasing numbers of Kentucky research cigarettes K3R4F and K1R5F and 24-h post-incubation. The curve was calculated from the data achieved by the WST-1 assay. The calculation was performed using the software Curve Expert 1.4 
exposure to the smoke of 12 and more cigarettes. On the basis of these data, dose-response curves (Fig. 2b) and values for the effective dose were calculated for each cigarette type (K3R4F: $\mathrm{ED}_{10}: 2.48$ cigarettes, $\mathrm{ED}_{50}: 4.63$ cigarettes; K1R5F: $\mathrm{ED}_{10}$ : 7.79 cigarettes, $\mathrm{ED}_{50} 32.37$ cigarettes) by nonlinear regression software Curve Expert 1.4 (Harris Model) with a correlation coefficient of 0.995 and 0.97 , respectively. Accordingly, the different cytotoxic potentials of both cigarettes became apparent.

Other markers reflecting exposure-related cell damage like oxidative stress, DNA damage, cytoskeletal changes or immunomodulation can also be analyzed in a comparable way

\section{Genotoxicity-Ames assay}

To analyze the genotoxic potency of complex mixtures like whole smoke (WS), the CULTEX ${ }^{\circledR}$ RFS module can also be adapted to expose $S$. typhimurium tester strains in a modified Ames assay at the air-agar interface $[25,26]$.

The exposure of bacteria to synthetic air up to $1 \mathrm{~h}$ did not change the number of induced revertants in comparison to the spontaneous revertants, which were in the same range.

S. typhimurium strains TA98 and TA100 were exposed at the air-agar interface with mainstream smoke or the filtered smoke of the different cigarette brands to analyze the discriminatory power of the method. The mutagenicity of cigarettes was determined dependent on their tar content. TA98 detected mutagenicity of whole smoke of all analyzed brands in a dose-dependent manner (Fig. 3a). Mutagenicity increased by increasing the tar content of the cigarettes except in the monitor cigarette CM5 (15 mg tar/cigarettes) which revealed a mutagenic activity below that of brand $\mathrm{C} 1$ with $7 \mathrm{mg}$ tar/cigarette. K3R4F (9.4 mg tar/cigarette) showed the highest mutagenicity, followed by brand $\mathrm{C} 1$ (7 mg tar/cigarette), CM5 (15 mg tar/cigarette) and K1R5F (1.67 mg tar/cigarette).

The GVP was analyzed with strain TA100 (Fig. 3b). Mutagenicity increased with rising tar content of the cigarettes. The highest mutagenicity was detected with brand $\mathrm{C} 1$ followed by brands $\mathrm{CM} 5, \mathrm{~K} 3 \mathrm{R} 4 \mathrm{~F}$, and K1R5F.

The different activities of mainstream smoke and the gas vapor phase demonstrated that the tar content alone cannot explain the mutagenic activity of a cigarette, but rather that the composition of the tar or modifications of the cigarette (filter design, ventilation, etc.) are responsible for its biological activity.

\section{Discussion}

In the EU legislation, the framework REACH came into effect on 1 st July 2007 , boosting the protection of consumers and

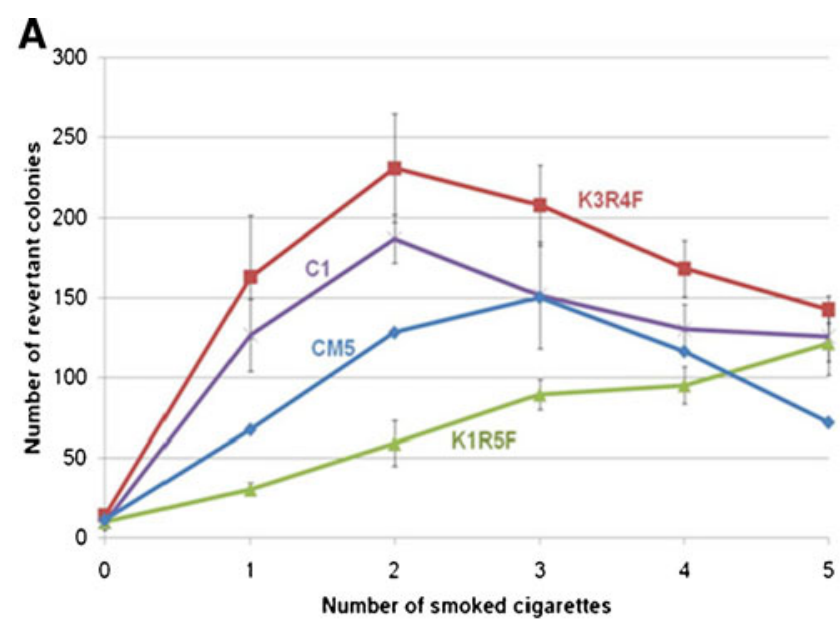

B

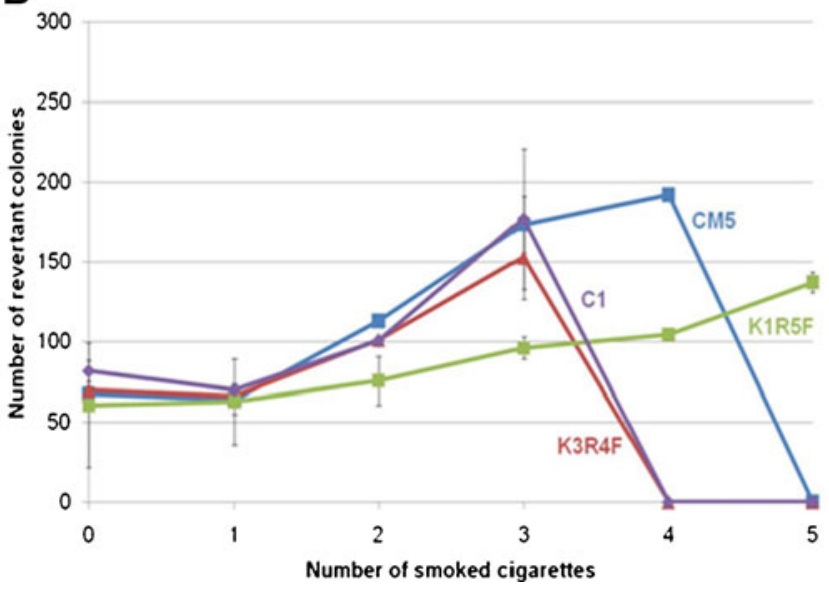

Fig. 3 Induction of revertants in A $S$. typhimurium strain TA98 after exposure of the bacteria with diluted mainstream smoke and B in $S$. typhimurium strain TA100 after exposure with diluted filtered smoke (gas vapor phase) of cigarettes with different tar content (K3R4F: $9.5 \mathrm{mg}$ tar/cigarette, K1R5F: $1.67 \mathrm{mg}$ tar/cigarette, CM5: $15 \mathrm{mg}$ tar/ cigarette, $\mathrm{C} 17 \mathrm{mg}$ tar/cigarette). "0 cigarettes" indicate synthetic air control. The values are given as mean of three replicates + standard deviation. Dilution: $1.0 \mathrm{l} / \mathrm{min}$ with synthethic air; flow rate through the chambers: $10 \mathrm{ml} / \mathrm{min}$

animals. Due to the fact that $86 \%$ of the safety testing data for existing chemicals are lacking [30,31], the EU legislation urged to list such data for chemicals produced or marketed in quantities of more than $1 \mathrm{t}$ per year [32-36]. Several attempts were made to calculate the financial and experimental investments, especially with regard to animal numbers required [33-36]. Taking into the consideration the missing information in the field of acute inhalation toxicology [33, $35,37]$ and the demand of the new legislation to use alternative methods, it became obvious that there will be a demand for in vitro test systems for toxicological screening comprising acute cytotoxic or genotoxic effects. Although in vitro inhalation tests cannot replace animal testing completely at present, the availability of such test systems may significantly reduce the number of animal experiments. For instance, the in vitro data can provide further crucial 
preliminary information leading to the exclusion of pretested substances from animal tests. Besides the reduction in the number of animal experiments the use of in vitro methods provides more basic benefits [38]. The space required is negligibly small, and furthermore it is much more time- and cost effective than traditional animal tests.

The use of in vitro methods in the field of inhalation toxicology exhibits some special features especially concerning technical equipment and exposure procedures. Simulating the in vivo situation, target cells of the respiratory tract (bronchial epithelial cells, alveolar cells) are exposed directly at the air-liquid interface, meaning that the cultivated cells are in direct contact with the inhalable compounds. Specially designed exposure devices have been used successfully in studying such actual atmospheres [3, 4, 39-43]. Our latest development, the CULTEX ${ }^{\circledR}$ RFS module, is characterized by a radial distribution of the test atmosphere from one sampling point to the cells, resulting in a homogeneous deposition of particulate matter on the cells which can be calculated according to a simplified model distinguishing between sedimentation, differentiation and electrical deposition (Fig. S1 in the ESM).

The efficiency in providing a close contact between cells and particles allows the analysis of dose-response relationships. In our experiments, we exposed a human bronchial epithelial cell line (16HBE14o-) to cigarette smoke generated from the research cigarettes K1R5F and K3R4F, which differ considerably in their tar content. The exposure of the cells to increasing numbers of the corresponding cigarettes resulted in a decrease of cell viability. The calculated dose-response curves and key values $\left(\mathrm{ED}_{50}\right)$ for a direct comparison of both cigarettes revealed their different cytotoxic potency. The most common assessment of cigarette smoke cytotoxicity is based on the evaluation of condensates and extracts of the gas vapor phase [44, 45] also resulting in dose response relationships, although the test material did not reflect the composition of the native test atmosphere, e.g., with regard to short living radicals and gaseous compounds. Also interactions with medium components have to be taken in consideration, distorting the biological effects. Accordingly, the direct exposure method of cultivated cells at the air-liquid interface is recommended for analyzing airborne material in simulation to the in vivo situation $[7,18]$. The efficiency of the method with regard to stability and reproducibility and their relevance to be applied to reducing numbers of experimental animals in the field of inhalation toxicology have to be proven in validation studies. At the moment, a prevalidation study on the CULTEX ${ }^{\circledR}$ method meaning direct exposure of cultivated cells at the air-liquid interface with special emphasis on particulate matter is under way (BMBF project 0315710A).

Another approach used is the direct exposure strategy for exposing bacteria at the air-agar interface in a modified
Ames assay $[25,26]$ to analyze the mutagenic potency of cigarette smoke. The "Bacterial Reverse Mutation Assay" is generally accepted (OECD 471) and has been widely used for soluble compounds, condensates and extracts of complex mixtures by combining test substances and bacteria within the overlay agar. The methodological approaches for investigating volatile compounds, gases or complex native mixtures followed another strategy [25, 26, 28, 46, 47]. In accordance with the method described by Araki et al. [28], we plated the bacteria directly on the surface of selective agar (spreadculture method) and exposed them to a continuous stream of native whole (WS) and filtered cigarette smoke (GVP) of four cigarettes (K3R4F, C1, CM5, K1R5F) with different tar content (ranging from 1.67 to $15 \mathrm{mg}$ per cigarette). The experiments resulted in a dose-dependent (number of cigarettes smoked) induction of revertants for both test atmospheres (Fig. 3a, b). The discriminating capacity of the modified Ames assay, known from studies with cigarette condensates [44] could also be demonstrated for filtered and unfiltered native mainstream cigarette smoke. In summary, these studies showed that the mutagenic signals of native test atmospheres, composed of particulate and gaseous compounds, can be determined by direct exposure methods as well as to differentiate between the mutagenicity of whole smoke and its gas phase in a dose-dependent manner. Qualitative and quantitative differences between complex atmospheres can be discriminated according to their mutagenic activity.

The possibility to test native harmful atmospheres for the screening of chemicals, industrial products as well as complex atmospheres constitutes an interesting domain in the context of acute toxicity and biological activities. The application of direct exposure methods to analyze the biological effects of inhalable substances offers new ways to establish dose-response relationships of such substances by simulating the in vivo situation. The challenge of such studies is the multidisciplinary approach combining biological and technical as well as aerosol physical aspects in such a cell-based approach.

Open Access This article is distributed under the terms of the Creative Commons Attribution Noncommercial License which permits any noncommercial use, distribution, and reproduction in any medium, provided the original author(s) and source are credited.

\section{References}

1. Barnes PJ (2010) New therapies for chronic obstructive pulmonary disease. Med Princ Pract 19(5):330-338

2. Lopez AD, Murray CC (1998) The global burden of disease, 1990-2020. Nat Med 4(11):1241-1243

3. Aufderheide M, Costa DL, Devlin R, Feron V, Harkema JR, Hayashi Y, Pauluhn J, Spielmann H (2005) Experimental Assessment of the toxicological effects of inhaled complex mixtures on the respiratory system, 23-25 April 2005, Barcelona, 
Spain. Summary and conclusions of the review committee. Exp Toxicol Pathol 57(Suppl 1):239-243

4. Aufderheide M, Mohr U (2000) CULTEX - an alternative technique for cultivation and exposure of cells of the respiratory tract to airborne pollutants at the air/liquid interface. Exp Toxicol Pathol 52(3):265-270

5. BeruBe K, Aufderheide M, Breheny D, Clothier R, Combes R, Duffin R, Forbes B, Gaca M, Gray A, Hall I, Kelly M, Lethem M, Liebsch M, Merolla L, Morin JP, Seagrave J, Swartz MA, Tetley TD, Umachandran M (2009) In vitro models of inhalation toxicity and disease. The report of a FRAME workshop. Altern Lab Anim 37(1):89-141

6. Bitterle E, Karg E, Schroeppel A, Kreyling WG, Tippe A, Ferron GA, Schmid O, Heyder J, Maier KL, Hofer T (2006) Dosecontrolled exposure of A549 epithelial cells at the air-liquid interface to airborne ultrafine carbonaceous particles. Chemosphere 65(10): 1784-1790

7. Fukano Y, Ogura M, Eguchi K, Shibagaki M, Suzuki M (2004) Modified procedure of a direct in vitro exposure system for mammalian cells to whole cigarette smoke. Exp Toxicol Pathol 55 (5):317-323

8. Lenz AG, Karg E, Lentner B, Dittrich V, Brandenberger C, Rothen-Rutishauser B, Schulz H, Ferron GA, Schmid O (2009) A dose-controlled system for air-liquid interface cell exposure and application to zinc oxide nanoparticles. Part Fibre Toxicol 6:32

9. Mülhopt S, Paur H-R, Diabate S, Krug HF (2008) In: Kim KJ, Platt U (eds) Advanced environmental monitoring, 1st edn. Dordrecht, Springer

10. Tarkington BK, Wu R, Sun WM, Nikula KJ, Wilson DW, Last JA (1994) In vitro exposure of tracheobronchial epithelial cells and of tracheal explants to ozone. Toxicology 88(1-3):51-68

11. Atsuta J, Sterbinsky SA, Plitt J, Schwiebert LM, Bochner BS, Schleimer RP (1997) Phenotyping and cytokine regulation of the BEAS-2B human bronchial epithelial cell: demonstration of inducible expression of the adhesion molecules VCAM-1 and ICAM-1. Am J Respir Cell Mol Biol 17(5):571-582

12. Berube K, Pitt A, Hayden P, Prytherch Z, Job C (2010) Filter-well technology for advanced three-dimensional cell culture: perspectives for respiratory research. Altern Lab Anim 38(Suppl 1):49-65

13. Ehrhardt C, Laue M, Kim KJ (2008) In: Ehrhardt C, Kim KJ (eds) Drug absorption studies: in situ, in vitro and in silicio models (biotechnology: pharmaceutical aspects), 1st edn. Springer, Berlin

14. Forbes B, Shah A, Martin GP, Lansley AB (2003) The human bronchial epithelial cell line 16HBE14o- as a model system of the airways for studying drug transport. Int J Pharm 257(1-2):161-167

15. Foster KA, Oster CG, Mayer MM, Avery ML, Audus KL (1998) Characterization of the A549 cell line as a type II pulmonary epithelial cell model for drug metabolism. Exp Cell Res 243 (2):359-366

16. Sun W, Wu R, Last JA (1995) Effects of exposure to environmental tobacco smoke on a human tracheobronchial epithelial cell line. Toxicology 100(1-3):163-174

17. Zhu Y, Chidekel A, and Shaffer TH (2010) Cultured human airway epithelial cells (calu-3): a model of human respiratory function, structure, and inflammatory responses. Crit Care Res Pract (in press)

18. Bérube KA, Pit A, Hayden PZP, Job C (2010) Human primary bronchial lung cell constructs: the new respiratory models. Toxicology 278:311-318

19. Choe MM, Tomei AA, Swartz MA (2006) Physiological 3D tissue model of the airway wall and mucosa. Nat Protoc 1(1):357-362

20. Hermanns MI, Kasper J, Dubruel P, Pohl C, Uboldi C, Vermeersch V, Fuchs S, Unger RE, Kirkpatrick CJ (2010) An impaired alveolar-capillary barrier in vitro: effect of proinflammatory cytokines and consequences on nanocarrier interaction. J R Soc Interface 7(Suppl 1):S41-S54
21. Muller L, Riediker M, Wick P, Mohr M, Gehr P, Rothen-Rutishauser B (2010) Oxidative stress and inflammation response after nanoparticle exposure: differences between human lung cell monocultures and an advanced three-dimensional model of the human epithelial airways. J R Soc Interface 7(Suppl 1):S27-S40

22. Papritz M, Pohl C, Wubbeke C, Moisch M, Hofmann H, Hermanns MI, Thiermann H, Kirkpatrick CJ, Kehe K (2010) Side-specific effects by cadmium exposure: apical and basolateral treatment in a coculture model of the blood-air barrier. Toxicol Appl Pharmacol 245(3):361-369

23. Pohl C, Hermanns MI, Uboldi C, Bock M, Fuchs S, Dei-Anang J, Mayer E, Kehe K, Kummer W, Kirkpatrick CJ (2009) Barrier functions and paracellular integrity in human cell culture models of the proximal respiratory unit. Eur J Pharm Biopharm 72 (2):339-349

24. Rothen-Rutishauser BM, Kiama SG, Gehr P (2005) A threedimensional cellular model of the human respiratory tract to study the interaction with particles. Am J Respir Cell Mol Biol 32 (4):281-289

25. Aufderheide M, Gressmann H (2007) A modified Ames assay reveals the mutagenicity of native cigarette mainstream smoke and its gas vapour phase. Exp Toxicol Pathol 58(6):383-392

26. Aufderheide M, Gressmann H (2008) Mutagenicity of native cigarette mainstream smoke and its gas/vapour phase by use of different tester strains and cigarettes in a modified Ames assay. Mutat Res 656(1-2):82-87

27. Maron DM, Ames BN (1983) Revised methods for the Salmonella mutagenicity test. Mutat Res 113(3-4):173-215

28. Araki A, Kamigaito N, Sasaki T, Matsushima T (2004) Mutagenicity of carbon tetrachloride and chloroform in Salmonella typhimurium TA98, TA100, TA1535, and TA1537, and Escherichia coli WP2uvrA/pKM101 and WP2/pKM101, using a gas exposure method. Environ Mol Mutagen 43(2):128-133

29. De Serres FJ, Shelby MD (1979) Recommendations on data production and analysis using the Salmonella/microsome mutagenicity assay. Environ Mutagen 1(1):87-92

30. European Commission (2001) White Paper: strategy for a future chemicals policy. Commission of the European Communities, Brussels

31. Roe D, Pease D, Florini K, Silbergeld E (1997) Toxic ignorance: the continuing absence of basic health testing for top selling chemicals in the United States. Environmental Defense Fund, Washington

32. REACH (2006) Regulation (EC) No 1907/2006 of the European parliament and of the council. Official Journal of the European Union

33. Hofer T, Gerner I, Gundert-Remy U, Liebsch M, Schulte A, Spielmann H, Vogel R, Wettig K (2004) Animal testing and alternative approaches for the human health risk assessment under the proposed new European chemicals regulation. Arch Toxicol 78 (10):549-564

34. IEH (2001) Testing requirements for proposals under the EC white paper 'strategy for a future chemicals policy'. IEH report, Leicester

35. Pedersen F, de Bruijn J, Munn S, van Leeuwen K (2003) Assessment of additional testing needs under REACH-effects of (Q)SARs, risk based testing and voluntary industry initiatives. JRC Report EUR 20863

36. van der Jagt K, Munn SJ, Torslov J, de Bruijn J (2004) Alternative Approaches Can Reduce the Use of Test Animals under REACH. European Commission, Joint Research Centre, Report EUR 21405 EN

37. Rovida C, Hartung T (2009) Re-evaluation of animal numbers and costs for in vivo tests to accomplish REACH legislation requirements for chemicals - a report by the transatlantic think tank for toxicology (t(4)). ALTEX 26(3):187-208

38. Berube KA (2011) Alternatives for lung research: stuck between a rat and a hard place. ATLA 39(2):121-130 
39. Aufderheide M (2005) Direct exposure methods for testing native atmospheres. Exp Toxicol Pathol 57(Suppl 1):213-226

40. Aufderheide M (2008) An efficient approach to study the toxicological effects of complex mixtures. Exp Toxicol Pathol 60 (2-3):163-180

41. Olivera DS, Boggs SE, Beenhouwer C, Aden J, Knall C (2007) Cellular mechanisms of mainstream cigarette smoke-induced lung epithelial tight junction permeability changes in vitro. Inhal Toxicol 19(1):13-22

42. Pariselli F, Sacco MG, Rembges D (2006) Dynamic in-vitro exposure of human derived cells to indoor priority pollutants. European Commission, Joint Research Centre, Report EUR 22285 EN

43. Seagrave J, Dunaway S, McDonald JD, Mauderly JL, Hayden P, Stidley C (2007) Responses of differentiated primary human lung epithelial cells to exposure to diesel exhaust at an air-liquid interface. Exp Lung Res 33(1):27-51
44. Johnson MD, Schilz J, Djordjevic MV, Rice JR, Shields PG (2009) Evaluation of in vitro assays for assessing the toxicity of cigarette smoke and smokeless tobacco. Cancer Epidemiol Biomarkers Prev 18(12):3263-3304

45. Roemer E, Ottmueller TH, Zenzen V, Wittke S, Radtke F, Blanco I, Carchman RA (2009) Cytotoxicity, mutagenicity, and tumorigenicity of mainstream smoke from three reference cigarettes machine-smoked to the same yields of total particulate matter per cigarette. Food Chem Toxicol 47(8):18101818

46. Araki A, Noguchi T, Kato F, Matsushima T (1994) Improved method for mutagenicity testing of gaseous compounds by using a gas sampling bag. Mutat Res 307(1):335-344

47. Arroyo PL, Hatch-Pigott V, Mower HF, Cooney RV (1992) Mutagenicity of nitric oxide and its inhibition by antioxidants. Mutat Res 281(3):193-202 